DOI: $10.17516 / 1997-1370-0349$

УДК 008, 81-119

\title{
Dialect Worldview
}

\section{as a Linguo-Culturological Phenomenon}

\author{
Lyudmila A. Araevaa, Veronika A. Kameneva ${ }^{a}$ \\ and Anastasiya A. Lushpey ${ }^{\text {** }}$ \\ ${ }^{a}$ Kemerovo State University \\ Kemerovo, Russian Federation \\ ${ }^{b}$ Kemerovo State University of Culture and Arts \\ Kemerovo, Russian Federation
}

Received 07.11.2018, received in revised form 26.11.2018, accepted 04.12.2018

\begin{abstract}
Language interprets the world and human existence in it. Following the path laid by Étienne de Condillac and Friedrich von Humboldt, modern linguists try to understand how the thought takes shape in the language, i. e. the epistemological essence of language. The idea of the linguistic worldview was coined within the Neo-Humboldtism movement. The term linguistic worldview was derived from the concept of linguistic worldview. The study of the dialect derivatives of the Russian language is relevant in that it fills in the gaps in the description of the dialect worldview. The current research features dialectal lexical derivatives. The present linguo-cultural analysis employed the method of propositional frame modeling. The present paper focuses specifically on the dialect derivatives with $-\mathrm{y} \omega / \mathrm{a} /$ $[-\mathrm{ush} / \mathrm{a} /]$ formant within the frame of axiological characteristics of rural women. The research revealed some stereotypical propositions within the framework of thought, as well as the emotional perception of the women referred to, thus revealing the unique nature of the rural worldview. The spiritual values that shape the dialect worldview are verbalized in the nomination of human qualities that are significant for the dialect speaker. Of all the formants in the dialect system, the dialect speaker intuitively selects the one that can explicate the whole range of evaluations that shaped the traditional value system. Thus, the propositional frame analysis of derivatives within one particular derivational niche makes it possible to describe the fragments of a unique dialect worldview and the peculiarities of its emotional interpretation by rural residents.
\end{abstract}

Keywords: dialect worldview, linguistic stigmatization, pejorative, derivational formant, propositional structure, proposition, propositional frame modeling method.

Research area: culturology.

Citation: Araeva, L.A., Kameneva, V.A., Lushpey, A.A. (2018 online). Dialect worldview as a linguo-culturological phenomenon. J. Sib. Fed. Univ. Humanit. soc. sci., 2022 15(10), 1500-1507. DOI: $10.17516 / 1997-1370-0349$

(C) Siberian Federal University. All rights reserved

* Corresponding author E-mail address: araeva@list.ru; russia_science@mail.ru; ana1534@ya.ru 


\author{
Л.А.Араева ${ }^{a}$ В.А. Каменева ${ }^{a}$ А.А. Лушпей ${ }^{6}$ \\ ${ }^{a}$ Кемеровский государственный университет \\ Российская Федерачия, Кемерово \\ ${ }^{6}$ Кемеровский государственный институт культуры \\ Российская Федераиия, Кемерово
}

\begin{abstract}
Аннотация. Язык является интерпретацией окружающего мира и человеческого бытия в нем. Работы Э.Б. де Кондильяка и В. фон Гумбольдта предопределили обращение современной лингвистики к выявлению особенностей реализации мысли в языке, гносеологической сущности языка. Представители неогумбольдтианства обосновали существование языковой картины мира. Это привело к появлению наряду с термином «языковая картина мира» термина «диалектная картина мира». Рассмотрение диалектных дериватов русского языка является актуальным и направлено на восполнение пробелов в описании диалектной картины мира. Особая значимость настоящего исследования связана с рассмотрением диалектной производной лексики в рамках лингвокультурологического аспекта с использованием метода пропозиционально-фреймового моделирования. В статье подвергаются анализу диалектные дериваты, входящие в словообразовательную нишу с формантом -уш/a/ в пределах фрейма «аксиологическая характеристика сельских женщин». Выявлены стереотипные пропозиции в рамках направляющих мысль пропозициональных структур, а также эмоциональное восприятие именуемых женщин, что позволило увидеть уникальность мировидения сельских жителей. Заложенные в диалектной картине мира духовные ценности вербализуются в акте номинации значимых для диалектоносителя человеческих качеств. Из функционирующих в диалектной системе формантов носитель диалекта интуитивно выбирает тот, который способен эксплицировать спектр оценочных суждений, сформированных в соответствии с традиционной системой ценностей. Пропозиционально-фреймовый анализ производных единиц в границах словообразовательной ниши позволяет представить фрагменты уникальной диалектной картины мира и особенностей ее эмоциональной интерпретации сельскими жителями.
\end{abstract}

Ключевые слова: диалектная картина мира, языковая стигматизация, пейоративность, словообразовательный формант, пропозициональная структура, пропозиция, метод пропозиционально-фреймового моделирования.

Научная специальность: 24.00.00 - культурология.

\section{Introduction}

Traditionally, the phenomenon of the dialect worldview is considered in the context of the German philosophy of the $20^{\text {th }}$ century. The philosophy in question predetermined the emergence and empirical substantiation of a number of terms, e. g. linguistic worldview and dialect worldview. As a rule, the concept of the linguistic worldview is interpreted from two main viewpoints. On the one hand, there is the school of Friedrich von Humboldt and Neo-Humboldtism, represented by Leo Weisgerber, with its internal form of language. On the one hand, there is the American ethno-linguistics with its hypothesis of linguistic relativity developed by Edward Sapir and Benjamin Lee Whorf. 
The concept of dialect worldview sprung from idio-ethnic language studies. The dialect is opposed to the national language, first of all, because it lacks codification. However, there are other peculiarities, e. g. its archaic character, alternative form of learning, and a wide range of connotation units, which can be pejorative and may even trigger the processes of language stigmatization.

The term dialect worldview has a fairly broad semantic field of definitions. Most often, it is defined as a certain structure of a system of specific linguistic units explicated in accordance with the hierarchy of the language in general. Dialectisms are usually considered at the word-formation level, since it reflects the cognitive processes of speech generation. The dialectal worldview is known for its natural character, which is determined by the relative isolation of the dialect community. It is closely connected with the peculiarities of rural lifestyle and the proximity to nature. As a result, the traditional system of values often acquires rather specific forms in dialect speakers. An analysis of dialect speech can reveal some of these peculiarities.

Initially, domestic dialect studies focused mainly on the phonetic and lexical levels. However, they received a new aspect in the late $20^{\text {th }}$ century, when word formation cemented its place as an independent linguistic science. At present, cognitive approach to the word-formation system and its complex units (word-formation types, nests, niches, etc.) is becoming more and more relevant. The Kemerovo Derivatological School is often named among the fundamental works that investigate the dialect as a system of wordformation units at the syntagmatic and paradigmatic levels (Araeva, 2009; Araeva et al., 2015; Evseeva, Kreidlin, 2017; Araeva, Obraztsova, 2016; Proskurina, 2010; Araeva et al., 2018 et al.).

\section{Conceptual basis of the study}

The present research was based on the concept of mutual conditionality of language and thought (see works by F. von Humboldt, E. S. Kubryakova, A. A. Potebni et al.) and the recognition of language as a symbolic embodiment of culture (N. N. Boldyrev, Yu. S. Stepanov et al.). These approaches were fundamental in revealing the peculiarities of the way dialect speakers interpret the world in the case of the word-building niche with a formant -yw/a/ [-ush/a/]. The study employed the method of the propositional frame modeling. This method has been used by the Kemerovo Derivatological School for 27 years and lies at the basis of more than 1000 scientific works featuring word-formation types, niches, and derivational nests of singleroot words, word-formation and propositional synonyms, multi-valued derivative words, and compact thematic clusters of derivatives in the Russian, Chinese, and Turkic languages (see the works by L. A. Araeva, E. V. Belogorodtseva, O. A. Bulgakova, K. A. Demidenko, I. V. Evseeva, T. V. Zhukova, P. A. Katysheva, T. V. Kovaleva, U. V. Kereksibesova, M. S. Kosyreva, I. A. Krym, V.S. Kuznetsova, S. I. Li, E. E. Maksakova, M. N. Obraztsova, S. V. Oleneva, M. A. Osadchy, A. V. Proskurina, S. K. Sokolova, M. J. Tagaev, I.P. Falomkina and A. N. Shabalina).

The analysis reveals the propositional knowledge structures, i. e. abstract evaluations of predicatively connected actants. These propositionally organized evaluations are identical for all representatives of modern civilization, which is consistent with the idea coined by $\mathrm{F}$. von Humboldt. According to it, all languages are identical at their most abstract level, so that it is possible to speak about a single human language (Humboldt, 1984). Propositional structures are verbalized in propositions, which manifest a unique way of world cognition shaped under the influence of a specific linguistic form and ethnocultural peculiarities. Thus, the semantics of the derived word is a reduced judgment. As a result, the research uses the method of the propositional frame modeling, since it manifests the epistemological essence of the subject.

\section{Problem statement}

The article deals with the frame that presents axiologically colored nominations of women. It features the derivational niche with the formant $-\mathrm{y} w / \mathrm{a} /(-\mathrm{ush} / \mathrm{a} /)$. Human cognition of the world is emotional; therefore, a description of the axiological component that reveals a stereotypical attitude towards a person in rural areas makes a substantial contribution to the dialect worldview studies. 


\section{Methods}

Along with the method of the propositional frame modeling, the research employed the descriptive method and the method of macromodeling. The study was based on derivatives with formant $-\mathrm{y} w / \mathrm{a} /(-\mathrm{ush} / \mathrm{a} /)$ obtained with the help of the continuous sampling method from various dictionaries of Russian folk dialects.

\section{Discussion}

The research focused on the word-building aspect of dialectisms, since the level of wordformation meanings presents the knowledge native speakers have about the world around them. In a way, this level contains reduced and propositionally organized judgments about a particular subject. Along with the motivating word, the formant is an important structural component of the lexical word-formation meaning: it is the functional carrier of word-formation and lexical meaning. Among a wide range of Russian formants, archaic suffixes are of particular interest to researchers. They function mainly in the dialect system of the Russian national language. Formant $-\mathrm{yw} / \mathrm{a} /(-\mathrm{ush} / \mathrm{a} /)$ is one of such formants. It is a means of language stigmatization used by the dialect speaker to characterize people in various aspects of life.

The hypothesis about the predominantly dialectal sphere of its functioning can be proved by the fact that in S. I. Ozhegov and N. Yu. Shvedova's Explanatory Dictionary of the Russian language there are only seven derivatives with -уш/a/: волокуша (a drag), горбуша (pink salmon), дорогуша (sweetheart), квакуша (a frog), кликуша (a calamity howler), копуша (a slow one), чинуша (a bureaucrat). In the absolute majority of the cases, they are marked as colloquial or slangy (Ozhegov, Shvedova, 2006). However, various dictionaries of Russian folk dialects contain about six hundred derivative words with this formant. The analysis of these derivatives in the dialectal system of the Russian language allowed the authors to reveal the peculiarities of the worldview typical of dialect speakers.

A word-formation niche includes word formation types with identical formant and motivating units of different lexical and grammatical classes. A cognitive analysis of derivatives in a word-formation niche is promising and relevant; however, it has long been on the periphery of science. There has been only one work in the cognitive linguistics so far, in which the wordformation niche with a formant $-\mathrm{H} / \mathrm{g} /[-\mathrm{n} / \mathrm{ya} /]$ was analyzed in Russian folk dialects at the level of the macrosystem (Falomkina, 2012).

Herewithin, a word-building niche is understood as a mental-linguistic category, the members of which are connected by a single formant and invariant word-formation meaning (for the types of word-formation, see (Araeva, 2009)). This category makes it possible to detect the mechanism of world cognition at the level of mundane consciousness of dialect speakers. Within one niche, fragments of the linguistic worldview are recorded. Propositional structures and propositions that form frames and stereotypical situations set the vector of thought in the cognition of the world. The method of propositional frame modeling makes it possible to demonstrate the mechanism of world perception by dialect speaker and their emotional attitude to the world.

The present paper features a frame that contains woman-naming dialectisms. The wide range of their emotional coloring, from meliorative and neutral to pejorative, is rather remarkable. However, there are more words with pejorative connotation, which indicates that the main function of the $-\mathrm{y} \omega / \mathrm{a} /$ formant is language stigmatization.

Thus, one of the features of the dialectal categorization of the world within the word-forming niche with the $-\mathrm{y} ш / \mathrm{a} /$ formant is its emotional coloring. It implies that there are subjective elements in the speech-generating process of the dialect speaker, for whom emotional tone proves to be important.

We made a classification of dialectisms with -yш/a/ denoting women. The dialectisms were obtained from various dictionaries of Russian folk dialects. The classification made it possible to identify the propositional structures and propositions within the analyzed frame.

The semantics of the nuclear derivatives was based on a proposition that includes the naming units for women according to expediency and informativeness of the speech act: object (animated) according to its mental characteristic. 
Балабуша [balabusha] - a woman who chats a lot (Dahl, 1998: 42);

болтуша [boltusha] - a woman who talks a lot and can be deceitful (Dictionary of Russian folk dialects, 1968: 83);

брякуша [bryakusha] - a woman who talks too much and may say something indiscreet (Dictionary of Perm dialects, 2000: 62);

блекотуша [blekotusha] - a woman who talks too much, «beats the air» (Yaroslavl Regional Dictionary, 1981: 63);

щцекуша [shchekusha] - a woman who is a chatterbox (Dictionary of Russian dialects of Karelia, 2005: 927);

говоруша [govorusha] - a woman who talks a lot and does not care about her interlocutor (Yaroslavl Regional Dictionary, 1984: 84);

калякуша [kalyakusha] - a woman who talks a mile a minute (Dictionary of Russian folk dialects, 1977: 12);

хлопуша [khlopusha] - a chatterbox; a woman who likes talking a lot, singing songs, and telling tales (Dictionary of Perm dialects, 2002: 501);

потрекуиа [potrekusha] - a woman who talks a lot, blabs about (Dictionary of Perm dialects, 2002: 189);

секуша [sekusha] - a woman who talks a lot and quarrels with everyone (Dictionary of Russian folk dialects, 2000: 209);

тырыкуша [tyrykusha] - a woman who talks fast and incomprehensively (Dictionary of Russian folk dialects, 2012: 339);

цекуша [chekusha] - a woman who talks idly, speaks up when it is inappropriate (Dictionary of Perm dialects, 2002: 524);

щелкуша [shchelkusha] - a gossip (Vologda Regional Dictionary, 2006: 575).

The dominant class of these derivatives verbalizes the attitude of the dialect speaker towards a woman (sometimes towards a man) through the prism of traditional values, according to which it is bad to enter the process of communication for no obvious reason, and multuloquence is regarded as negative. Hence, the pejorative nature of the dialectism is achieved via language stigmatization with the help of the formant -yш/a/.

It should be noted that the expressive characteristic of women according to the manner of speaking was manifested in a large number of synonyms. Each of the synonyms stresses a characteristic feature that is not accepted by the society: she speaks too quickly / talks idly / gossips / quarrels / shouts / does not watch her tongue, etc.

This group was followed by another, semantically similar class of derived words. They nominate a woman according to the dichotomy of intelligibility / unintelligibility of her speech with an emphasis on the phonetic level: an object (animated) according to speech characteristics.

This group contained the following dialectisms:

Веньгуша [ven'gusha] - a woman who speaks in a high key (Dictionary of Russian folk dialects, 1969: 118);

вякуша [vyakusha] - a woman with a bad articulation who likes to talk, nevertheless (Dictionary of Russian folk dialects, 1970: 78).

The pejorative connotation revealed by the context indicated that the dialect speaker evaluates adequate perception of information as important and stigmatizes a woman incapable of adequate communication due to articulation defects.

Another group of derivatives with the formant -yш/a/ was especially important within the framework of the axiological approach to the definition of the dialectal worldview of Russian speakers. It identified a woman according to her appearance and neatness of clothes: object (animated) according to external characteristic.

нарядуша [naryadusha] - a woman who likes dressing-up (Dictionary of Russian folk dialects, 1985: 145);

толстуша [tolstusha] - an obese woman (Dictionary of Russian folk dialects, 2012: 213).

In the groups mentioned above, the pejorative character of the lexeme was dominant but not absolute. In the next group, the function of linguistic stigmatization of the formant -yш/a/ consolidated with the semantics of the producing words and was obvious in all the examples of female behavior as seen via the dialect worldview. The list of bad qualities included laziness, profligacy, disgust, anger, and malice, unsociable demeanor, frivolity, untidiness, etc.

бегуиа [begusha] - a woman who left her husband (Dictionary of Russian dialects in Karelia, 1995: 48); 
брезгуша [brezgusha] - a fastidious woman (Dictionary of Russian folk dialects, 1968: 174); дикуиа [dikusha] - a woman who is afraid of everyone, farouche (Dictionary of Russian folk dialects, 1972: 65);

дрызгуша [dryzgusha] - an untidy woman (Yaroslavl Regional Dictionary, 1985: 21);

моргуша [morgusha] - an unapt woman who cannot do anything about the house (Dictionary of Russian folk dialects, 1982: 257);

мякуша [myakusha] - a woman who needs to be forced to do something about the house (Dictionary of Russian folk dialects, 1983: 81);

неркуша [nerkusha] - a woman who constantly grumbles (Dictionary of Russian folk dialects, 1986: 143);

потаскуша [potaskusha] - a woman of easy virtue (Vologda Regional Dictionary, 2006: 396);

разваруша [razvarusha] - a lazy woman (Dahl, 1998: 184);

расхлябуша [raskhlyabusha] - a woman with a wobbly gait (Dictionary of Russian folk dialects, 2000: 298);

ругуша [rugusha] - a woman who uses strong language (Dictionary of Russian dialects in Karelia, 2002: 575);

таскуша [taskusha] - a woman who rarely happens at home, «drags about» (Dictionary of Russian folk dialects, 2010: 301);

хвостуша [khvostusha] - a woman who likes to brag (Dictionary of Russian dialects in Karelia, 2005: 710).

On the contrary, dialectal lexemes that identify women according to their social function have a neutral color, which is not characteristic of derivatives with the suffix $-\mathrm{yw} / \mathrm{a} /$ in words denoting animate objects. In this case, the neutral coloring can be explained by the fact that female behavior is assessed not in axiological but in functional aspect. For example, tools are mainly referred to by their function, without any emotional coloring:

Роговуша [rogovusha] - a woman who hands over the dowry of the bride and serves in the bedroom of the bride and groom (Vologda regional dictionary, 2006: 437); рогоуша [rogousha] - a woman serving the bride and giving her advice before the wedding night (Dictionary of Russian folk dialects, 2000: 126);

плакуша [plakusha] - a wailer at a funeral (Dictionary of Russian folk dialects, 1992: 79);

зыкуша [zykusha]; заплакуша [zaplakusha] - a leading singer at the lamentation of the bride during the wedding ceremony (Dictionary of Russian folk dialects, 1977: 323-324).

It should be noted that the nomination units denoting women according to their characterization value, which are based on the propositional structure object (animate) according to characteristic action, are formed mainly from the corresponding verbs. An adjective or a noun much less often serves as a motivating word. Thus, in the word-forming niche under consideration, Verb $+-y w / a /$ is the nuclear word-forming pattern at the frame level.

\section{Conclusion}

Cultural traditions and stereotyped thinking formation are reflected in the Russian national language. Dialect studies help to achieve a thorough understanding of the productivity of various word-building elements. Dialect studies make it possible to understand the nature of these elements and identify the patterns that have influenced the formation of the dialect norm. The analysis of the word-formation models presented in the paper allowed the authors to get an insight into the processes of evaluation and expressiveness formation.

The spiritual values that shape the dialect worldview are verbalized in the act of nomination of those human qualities that bear some significance for the dialect speaker. Intuitively, the dialect speaker chooses the formant that is able to explicate those evaluations which correspond with the traditional value system. The propositional frame analysis of derived units within the boundaries of a derivational niche allowed the authors to present some fragments of a unique dialect worldview and the peculiarities of its emotional interpretation by rural residents. 


\section{References}

Araeva, L.A. (2009). Slovoobrazovatel'nyi tip [Derivational type]. Moscow, LIBROKOM, $272 \mathrm{p}$.

Araeva, L.A., Artemova, T.V., Bulgakova, O.A., Obraztsova, M.N., \& Kreidlin, G.E. (2015). Propositional frame-based description of fragments of the Teleut linguistic worldview. In Review of European Studies, 7 (6), 295-301.

Araeva, L.A., Obraztsova, M.N., Proskurina, A.V., Abdullaeva, F.E., \& Guo Lihong (2018). Kak mysl' realizuetsia v iazyke: propozitsional'no-freimovaia organizatsiia gnezd odnokorennykh slov I ustoichivykh slovosochetanii s edinym iadernym komponentom v raznostrukturnykh iazykakh [How a thought is verbalized in the language: the propositional-frame organization of nests of single-root words and idioms with a single nuclear component in multi-structural languages]. In Sibirskii filologicheskii zhurnal [Siberian Journal of Philology], 4, 205-2015.

Evseeva,I.V.,Kreidlin,G.E.(2017).Freimovoemodelirovaniefragmentovleksiko-slovoobrazovatel'nykh gnezdssemantikoi 'zabolevanie' [Framemodelingoflexicalword-formationnestsfragmentswiththesemantics «disease»].In VestnikTomskogogosudarstvennogouniversiteta.Filologia [BulletinofTomskState University], 49, 5-23.

Falomkina, I.P. (2012). Propozitsional'no-freimovoe modelirovanie slovoobrazovatel'noi nishi s formantom -n/ial (na material russkikh narodnykh govorov) [Propositional frame modeling of the wordformation niche with formant-H/g/in Russian folk dialects]. Kemerovo, 262 p.

Humboldt von, F. (1984). Izbrannye trudy po iazykoznaniiu [Selected works on linguistics]. Moscow, Progress, $400 \mathrm{p}$.

Obraztsova, M.N. (2016). Kognitivno-diskursivnoe opisanie gnezda odnokorennykh slov (na material pchelovodcheskoi leksiki russkikh narodnykh govorov) [Cognitive-discursive description of the nest of oneroot words (the beekeeping vocabulary of Russian folk dialects)]. Kemerovo, Kemerovo State University, $206 \mathrm{p}$.

Proskurina, A.V. (2010). Vnutrenniaia forma slovoobrazovatel'nogo tipa (na materiale russkih narodnyh govorov) [Internal form of word-formation type in Russian folk dialects]. Kemerovo, Kemerovo State University, $199 \mathrm{p}$.

Sources

Borisova, A.N. (2000). Slovar' permskih govorov [Dictionary of Russian dialects]. Perm, 1, Kn. mir, $605 \mathrm{p}$.

Borisova, A.N. (2002). Slovar' permskih govorov [Dictionary of Russian dialects]. Perm, 2, Kn. mir, $574 \mathrm{p}$.

Dahl, V.I. (1998). Tolkovyi slovar' zhivogo velikorusskogo iazyka [The Explanatory Dictionary of the Living Great Russian Language]. Moscow, 1, 699 p.

Filin, F.P. (1968). Slovar' russkikh narodnykh govorov / Akademiia nauk SSSR; Institut russkogo iazyka [Dictionary of Russian folk dialects / USSR Academy of Sciences; Institute of Russian Language, Vocabulary]. Moscow, Nauka, 3, 362 p.

Filin, F.P. (1969). Slovar' russkikh narodnykh govorov / Akademiia nauk SSSR; Institut russkogo iazyka [Dictionary of Russian folk dialects / USSR Academy of Sciences; Institute of Russian Language, Vocabulary]. Moscow, Nauka, 4, 358 p.

Filin, F.P. (1970). Slovar' russkikh narodnykh govorov / Akademiia nauk SSSR; Institut russkogo iazyka [Dictionary of Russian folk dialects / USSR Academy of Sciences; Institute of Russian Language, Vocabulary]. Moscow, Nauka, 6, 360 p.

Filin, F.P. (1972). Slovar' russkikh narodnykh govorov / Akademiia nauk SSSR; Institut russkogo iazyka [Dictionary of Russian folk dialects / USSR Academy of Sciences; Institute of Russian Language, Vocabulary]. Moscow, Nauka, 8, 370 p.

Filin, F.P. (1977). Slovar' russkikh narodnykh govorov / Akademiia nauk SSSR; Institut russkogo iazyka [Dictionary of Russian folk dialects / USSR Academy of Sciences; Institute of Russian Language, Vocabulary]. Moscow, Nauka, 12, 368 p. 
Filin, F.P. (1977). Slovar' russkikh narodnykh govorov / Akademiia nauk SSSR; Institut russkogo iazyka [Dictionary of Russian folk dialects / USSR Academy of Sciences; Institute of Russian Language, Vocabulary]. Moscow, Nauka, 13, 360 p.

Filin, F.P. (1982). Slovar' russkikh narodnykh govorov / Akademiia nauk SSSR; Institut russkogo iazyka [Dictionary of Russian folk dialects / USSR Academy of Sciences; Institute of Russian Language, Vocabulary]. Moscow, Nauka, 18, 368 p.

Filin, F.P. (1983). Slovar' russkikh narodnykh govorov / Akademiia nauk SSSR; Institut russkogo iazyka [Dictionary of Russian folk dialects / USSR Academy of Sciences; Institute of Russian Language, Vocabulary]. Moscow, Nauka, 19, 360 p.

Filin, F.P. (1986). Slovar' russkikh narodnykh govorov / Akademiia nauk SSSR; Institut russkogo iazyka [Dictionary of Russian folk dialects / USSR Academy of Sciences; Institute of Russian Language, Vocabulary]. Moscow, Nauka, 21, 362 p.

Gerg, A.S. (1995). Slovar' russkikh govorov Karelii i sopredelnykh oblastei [Dictionary of Russian dialects of Karelia and adjacent areas]. St. Petersburg, Izd-vo S.-Peterb. un-ta, 2, 448 p.

Gerg, A.S. (2002). Slovar' russkikh govorov Karelii i sopredelnykh oblastei [Dictionary of Russian dialects of Karelia and adjacent areas]. St. Petersburg, Izd-vo S.-Peterb. un-ta, 5, 662 p.

Levichkin, A.I., Myznikov, S.A. (2006). Slovar' oblastnogo vologodskogo narechiia: po rukopisi P.A. Dilaktorskogo [Dictionary of the regional Vologda dialect: based on the P A. Dilaktorsky's manuscript]. St. Petersburg, Nauka, 677 p.

Lutovinova, I.S., Mikhailova, L.P. (2005). Slovar' russkikh govorov Karelii i sopredelnykh oblastei [Dictionary of Russian dialects of Karelia and adjacent areas]. St. Petersburg, Izd-vo S.-Peterb. un-ta, 6, $989 \mathrm{p}$.

Mel'nichenko, G.G. (1984). Iaroslavskii oblastnoi slovar': uchebnoe posobie [Yaroslavl Regional Dictionary: study guide]. Iaroslavl', 3, $132 \mathrm{p}$.

Mel'nichenko, G.G. (1985). Iaroslavskii oblastnoi slovar': uchebnoe posobie [Yaroslavl Regional Dictionary: study guide]. Iaroslavl', 4, $146 \mathrm{p}$.

Mel'nichenko, G.G. (1986). Iaroslavskii oblastnoi slovar': uchebnoe posobie [Yaroslavl Regional Dictionary: study guide]. Iaroslavl', 5, $131 \mathrm{p}$.

Ozhegov, S.I., Shvedova N.B. (2006). Tolkovyi slovar' russkogo yazyika: 80000 slov i frazeologicheskikh vyrazhenii [Explanatory dictionary of the Russian language: 80,000 words and phraseological expressions]. Moscow, TEMP, $938 \mathrm{p}$.

Sorokoletov, F.P. (1992). Slovar' russkikh narodnykh govorov / Rossiiskaia akademiia nauk; Institut lingvisticheskikh issledovanii [Dictionary of Russian folk dialects / Russian Academy of Sciences; Institute of Linguistic Studies]. St. Petersburg, Nauka, 27, 402 p.

Sorokoletov, F.P. (2000). Slovar' russkikh narodnykh govorov / Rossiiskaia akademiia nauk; Institut lingvisticheskikh issledovanii [Dictionary of Russian folk dialects / Russian Academy of Sciences; Institute of Linguistic Studies]. St. Petersburg, Nauka, 34, 368 p.

Sorokoletov, F.P. (2010). Slovar' russkikh narodnykh govorov / Rossiiskaia akademiia nauk; Institut lingvisticheskikh issledovanii [Dictionary of Russian folk dialects / Russian Academy of Sciences; Institute of Linguistic Studies]. St. Petersburg, Nauka, 43, 350 p.

Sorokoletov, F.P. (2012). Slovar' russkikh narodnykh govorov / Rossiiskaia akademiia nauk; Institut lingvisticheskikh issledovanii [Dictionary of Russian folk dialects / Russian Academy of Sciences; Institute of Linguistic Studies]. St. Petersburg, Nauka, 45, 344 p. 